\title{
Maqâsid Al-Syari'ah As A Guide In Establishing The Law
}

\author{
Abdurrakhman \\ \{wakhidunar@yahoo.co.id\} \\ Departement of Law, Universitas Sebelas Maret, Surakarta
}

\begin{abstract}
This study aims to find out the meaning of maqâsid al-syari'ah, and maqâsid alSyariah as guidelines for the law. This research uses doctrinal research (normative juridical), uses library research, and is qualitative, descriptive analysis. The results of the analysis show that knowledge of maqâsid al-syari'ah is essential. Understanding and understanding about maqâsid al-syari'ah can be used as an aid in understanding the Qur'an and as-sunnah, can also help resolve conflicting arguments (ta'arud al-dilalah) and what is very important is maqâsid al-shari'ah can be used as a guideline for the law. By knowing maqâsid al-syari'ah, it is easier for legal experts to practice law. If legal science cannot solve legal events, then by paying attention to the maqâsid al-shari'ah, every legal event will be easily resolved. Therefore it is very appropriate that maqsid al-syari'ah be used as a guideline in law
\end{abstract}

Keywords: Maqâsid al-Syariah, Guidelines, Law

\section{Introduction}

The concept of maqâsid al-syari'ah is a very important concept and does not escape the attention of scholars and experts in Islamic law. Most legal experts put the discussion in the Islamic Law, when they discussed qiyas, such as Imam al-Haramain al-Juwaini (died $478 \mathrm{AH}$ ) in his book al-Burhan, Al-Gazali (died $505 \mathrm{AH}$ ) also revealed maqsid al-shari ' ah in his book al-Mustashfa, as well as al-Razi (died $606 \mathrm{AH}$ ) in his book al-Mahsul fi ilmi Ushul Fiqh. Izz aldin ibn Abd al-Salam (died $660 \mathrm{AH}$ ) discussed it specifically in his book, among others, in the book al-Qawaid al-ahkam fi Masalih al-anam, also in his book Qawa'id al-Shugra. There are also scholars who discuss maqsid al-syari'ah in a particular chapter in the book such as Abu Ishaq al-Syatibi (died 790) in his book al-Muwafaqat, in volume II special discussion of the maqasid al-shari'ah. Maqâsid al-syari'ah has become a consideration as a sign in law. Such efforts then carried out by friends. Such efforts are evident in several legal provisions carried out by Umar Ibn al Khattab.

This research will discuss maqâsid al-syari'ah, but to get a more systematic and directed picture and understanding, the problems in this study will be focused on several issues, namely: how is the understanding of maqâsid al-syari'ah? How is maqâsid al-syari'ah a guideline for the law? 


\section{Method}

This study uses a type of doctrinal research (normative juridical), uses library research, and is qualitative, descriptive analysis. Library research, which examines some literature that are relevant to the problem of this writing. Qualitative research, according to Bogdan and Taylor; "qualitative methodologies refer to research procedures which produce descriptive data, people's own written or spoken words and observable behavior".

Creswell explains the following: Qualitative research begins with assumptions, a worldview, the possible use of a theoretical lens, and the study of research problems inquiring into the meaning individuals or groups ascribe to a social or human problem. To study this problem, qualitative researchers use an emerging qualitative approach to inquiry, the collection of data in a natural setting sensitive to the people and places under study, and data analysis that is inductive and establishes patterns or themes. The final written report or presentation includes the voices of participants, the reflexivity of the researcher, and an elaborate description and interpretation of the problem, and it extends the literature or signals a call for action.

Conclusion from the opinion of Bogdan, Taylor, and Creswell mentioned above, that qualitative research is a collection of information whose characteristics are in words and not a series of numbers. Qualitative research intends to understand the phenomenon of what is experienced by the subject of research, such as behavior, perception, motivation, actions and others holistically and by way of description in the form of words and language in a unique natural context and by utilizing various methods natural.

\section{Analysis}

\subsection{Understanding of Maqâsid al-Syari'ah}

Maqâsid al-syari'ah theory was only known in the fourth century Hijriah. The first time the term maqâsid al-syari'ah was used by Abu Abdalah al-Tirmizi al-Hakim, then the term maqâsid alshari'ah was popularized by al-Imam al-Haramain al-Juaini in several books he wrote and he was the one who first classifying maqâsid al-syari'ah into three broad categories, namely dharûriyyat, hâjiyat, and tahsîniyyat. Al-Juaini's thinking about maqsid al-shari'ah was further developed by Abu Hamid al-Ghazali $(505 \mathrm{H})$ who wrote at length about the maqsid al-shari'ah in his book Shifa al-Ghalīl fì Bāyan al-Syabah wa al -mukhil wa Masalik al-Ta'lil and alMusthasfa fí 'llm al-Ushul. Then al-Amidi further elaborated on this maqâsid al-syari'ah based on the basic principles of sharia, namely life, intellectual, religion, lineage and wealth. Furthermore, Maliki Shihab al-Din al-Qarafi added the basic principles of sharia with the principle of honor protection (al-'ird) this opinion supported by Taj al-Din Abdul Wahab Ibn alSubqi $(771 \mathrm{H})$ and Muhammad Ibn Ali al-Syaukani $(1255 \mathrm{H})$.

The discovery of maqsid al-syari'ah provides a conception for Islamic scholars to explain why there is and need for Islamic law. The purpose of Islamic law (maqâsid al-shari'ah) develops in the Islamic legal tradition through a long process. Although as a practice, the use of the objectives of the Shari'a as maslahah can be found since the time of the Companions, the root of the discussion about the maqâsid al-shari'ah itself develops gradually.

The essence of maqâsid al-syari'ah is maslahah, but it is not easy to know since when the idea of maslahah arose in the tradition of ushul fikih. Human kindness as the aim of Islamic law is indeed philosophical discussion, but the use of maslahah cannot be unknown in the religious 
practices of the time of the Prophet Muhammad. But if what is meant by the discussion of maqâsid al-syari'ah as a whole clear thought of its form, then al-Burhan by al-Juwaini has a clear conception of the maqâsid al-shari'ah.

The highlight of the discussion about maqsid al-syari'ah was stated by a Malikiyyah scholar, Abu Ishaq al-Syatibi. The purpose of Islamic law lies in how a common benefit is achieved. The measure of benefit refers to the doctrine of ushul fiqh which is known as al kulliyat al-khamsah (five pillars of the pillar) or in other words, called the maqasid al-syari'ah (universal goals of shari'ah). The five main pillars are hifdz al-dîn, guaranteeing religious freedom; hifdz al-nafs, maintaining survival; hifdz al-'aql, guarantees creativity thinking; hifdz al-nasl, guaranteeing descent and honor; hifdz al-mâl, ownership of property, property and wealth.

According to Izz al-Dīn Abd al-Salām maslahah and mafsadah are often meant with good and bad, benefits and harm, good and bad, useful and good because all maslahah are good, while mafsadah are all bad, harmful and not good for humans. In Al-Quran the word al-hasanat (kindness) is often used for the understanding of al-masalih (kindness), and the word al-sayyi'aat (evil) is used for the understanding of al-mafasid (damages). In another part Izz al-Dīn Abd alSalām suggests that there are four kinds of maslahah, namely delicacy, causes or ingredients, pleasure and causes or ingredients, while mafsadah also has four kinds, namely pain or discomfort, the cause or the things that caused it, the feeling of sadness and the cause or the things that caused it.

Islamic law has an essential purpose, namely the purpose of creating the law itself which is a benchmark for humans in order to achieve life happiness. The only lawmaker is Allah, who does nothing in vain. Everything He does has a purpose, namely for human benefit. The purpose of the law of God can be seen from two sides, that is seen in terms of humanity, namely the goal in terms of human interests or mukallaf and seen from the side of God as the maker of law, namely the purpose of God making law.

The purpose of Islamic law lies in how a common benefit is achieved. The measure of benefit refers to the doctrine of ushul fiqh which is known as al kulliyatul al-khams (five pillars of the pillars) or in other words, called the maqasid al-syari'ah (universal goals of shari'ah). The five main pillars are: hifdz al-dîn, guaranteeing religious freedom; hifdz al-nafs, maintaining survival; hifdz al-'aql, guarantees creativity thinking; hifdz al-nasl, guaranteeing descent and honor; hifdz al-mâl, ownership of property, property and wealth.

Maqasid al-syari'ah, in language, consists of two words namely, maqasid and syari'ah. Linguistically (etymologically), maqāsid al-sharī'ah is a term from a combination of two words: مقاصد (maqāsid) and (الثريعة al-sharī'ah). Maqāsid is the plural form dari kata مقصد (maqsad) which is derived from the word قصد (qasd), which has several meanings such as heading in a direction, destination, middle, balanced, fair, not transgressing, straight way, midway between excess- overage and lack.

Sharia, etymologically has many meanings, for example, sharia is interpreted as a path to a spring or place that humans and animals visit to get water, al-'atabah (door and stairway threshold), and al-tariqah al-mustaqimah (straight path, haq, right). This is as explained by Ahmad Rofiq that literally syari'ah means the road to the spring, or the place where river water passes. Its use in the Qur'an is interpreted as a clear path that brings victory.

In terms of terminology, some notions of maqâsid al-syari'ah expressed by some of the previous scholars are Al-lmam al-Syathibi: "Al-Maqâsid is divided into two: the first, relating to God's purpose as the shari'ah maker; and second, regarding the purpose of mukallaf ".

Returning to the meaning of Shari'a (Allah) is the benefit of His servants in two places; the world and the hereafter, and return to the purpose of mukallaf (man) is when His servant is recommended to live in benefit in the world and the hereafter, that is, by avoiding the damage 
that is in the world. Therefore, there must be an explanation between benefit (maslahah) and damage (mafsadah).

According to Abdul Wahab Khallaf: "The general purpose when Allah establishes His laws is to realize the benefit of man with the fulfillment of the needs of dharûriyyat, hâjiyat, and tahsîniyyat". From the two meanings above, it can be concluded that maqsid al-shari'ah is the purpose of Allah as the shari'ah maker to give benefit to humans, namely the fulfillment of the needs of dharûriyyat, hâjiyat and tahsîniyyat so that humans can live in goodness and can become servants of God who good.

The definition of maqâsid al-syari'ah as mentioned above seems to encourage Islamic jurists to give sharia limits in terms of terms that directly refer to the objectives of sharia in general. This can be seen from the limitations proposed by Mahmoud Syaltut that sharia is the rules created by God to be guided by humans in regulating relations with God, humans both fellow Muslims and non-Muslims, nature and all life. Likewise, the definition proposed by Ali al-Sayis stated that sharia is the laws given by God for His servants so that they believe and practice it for their sake in the world and the hereafter. From these two definitions it can be concluded that there is a relationship between the meaning of sharia and water in the sense of the relationship between means and purpose.

In discussing maqâsid al-syari'ah, al-Syatibi uses different words, but has the same meaning as maqâsid al-syari'ah, namely al-maqâsid al-syari'ah fi al syari'ah, maqâsid min syari 'al-hukm, that is the laws which are meant for the benefit of the world and the hereafter. The understanding given by as-Syatibi is based on the view that all obligations are created by Allah in order to realize human benefit. None of God's laws have no purpose. The law which has no purpose according to as-Syatibi is the same as taklif ma la yutaq (imposing something that cannot be implemented) and this is not possible in the laws of Allah. This view is strengthened by Muhammad Abu Zahrah who said that the essential purpose of Islamic law is the benefit of man and none of the laws are prescribed, both in the Qur'an and Sunnah, but in it there is a benefit.

\subsection{Maqâsid al-Syari'ah as a Guide to Law}

Judging from the prophet Muhammad SAW, it can be seen that the Islamic Shari'ah revealed by Allah is to realize human welfare as a whole. This is clearly stated in Surat al-Anbiyaa '(21) verse 107:

"And we did not send you but as a mercy to the universe."

$$
1076
$$

Nature is nothing but Allah. Therefore, the apostolate of the Prophet Muhammad SAW was not only for human beings but also for other God's creatures. However, other creatures that are generally created by God for humans, then the essence of the Shari'a of God is for humans.

Al-Syathibi in his book al-Muwafaqat fi Ushul al-Shari'ah argued that the main objective of Islamic law is to benefit humanity both in the world and in the hereafter. For that Imam alSyatibi has done istiqra (research) which was explored from the Qur'an and Sunnah, which concluded that the objectives of Islamic law (maqâsid al-shari'ah) in the world are five things, known as al-maqâsid al-kamsah namely:

a. Maintaining religion (hifdz al-dîn). What is meant by religion here is religion in the sense of a vertical relationship (worship of mahdhah) which is human relations with Allah SWT, including the rules regarding creed, prayer, zakat, fasting, hajj and other rules which include human relations with Allah SWT, and prohibition who left it. 
b. Maintaining oneself (hifdz al-nafs). Included in this second part, the prohibition of killing yourself and killing others, the prohibition of insulting and so on, and the obligation to protect yourself.

c. I am maintaining offspring and honor (hifdz al-nasl). Like the rules about marriage, prohibition of adultery, and others.

d. I am maintaining the property (hifdz al-mâl). Including this section, al-halal cash obligations, ban on stealing, and robbing people's property.

e. Maintaining reason (hifdz al-'aql). This includes the prohibition of drinking alcoholic beverages, and the obligation to study

As explained above, the main objective of Islamic law is to benefit humanity both in the world and in the hereafter. The benefit will be realized by the way of maintaining the needs that are dharûriyyat, hâjiyat, and the realization of the need for tahsîniyyat for humans themselves.

a. The need for dharûriyyat

Dharûriyyat, that is everything that becomes the foundation of the existence of human life must exist for their benefit. It can also be said that dharûriyyat is the enforcement of the benefits of religion and the world. That is, when dharûriyyat is lost, the benefit of the world and even the hereafter will disappear, and what will appear is precisely the damage and even the destruction of life. Dharûriyyat is also a condition where a mandatory need to be fulfilled immediately if ignored it will create a danger that is at risk of damage to human life. Dharûriyyat shows basic or primary needs that must always exist in human life. Dharûriyyat in shari'ah is something most basic compared to hâjiyat and tahsîniyyat. If dharûriyyat cannot be fulfilled, it will result in damage and disability hâjiyat and tahsîniyyat. But if hajjiyat and tahsîniyyat cannot be fulfilled, it will not result in damage and disability dharûriyyat. So, tahsîniyyat is guarded to help hâjiyat, and hâjiyat is guarded to help dharûriyyat.

Furthermore, dharûriyyat is divided into five points commonly known as al-kulliyat alkhamsah, namely: (1) maintaining religion (hifz al-dîn); (2) nurturing the soul (hifz al-nafs); (3) maintain mind (hifz al-'aql); (4) maintain offspring (hifz al-nasl); and (5) maintaining property (hifz al-mâl).

If the five things above can be realized, then there will be a life that is noble and prosperous in the world and the hereafter, or in the purpose of marriage is usually known as sakinah, mawaddah and rahmah. Sufficient community needs will have an impact called maslahah, because these five things are basic needs that must be met by each individual in the community. If one of the five things is not fulfilled properly, then life in the world will also not be able to run perfectly and moreover will have a negative impact on one's survival.

b. Hâjiyat needs

Hâjiyat needs are all things that are needed by humans to eliminate difficulties and reject all obstacles. That is, the absence of this spiritual aspect will not threaten the existence of human life to be damaged, but only cause difficulties and difficulties. The central principle in this aspect of hajjyat is to eliminate difficulties, ease the burden of taklif, and facilitate their affairs. For this purpose, Islam stipulates a number of provisions in several fields, mu'amalat, and 'uqubat (criminal).

This can be explained again in the following examples. In the field of worship, Islam provides rukhshah (dispensation) and relief if someone mukallaf experiences difficulties in carrying out a duty of worship. For example, it is permissible for someone not to fast in the month of Ramadan because he is traveling or sick. Likewise, one may market prayer if he is traveling and praying instead of ablution or bathing in junub when there is no clean water or cannot use water. 
In the field of mu'amalat, among others, Islam allows the sale and purchase of orders (istishna ') and the sale and purchase of greetings (buying and selling where goods are purchased indirectly when payment is made, but later, because the goods are purchased not in place when the transaction do). Likewise, a husband is allowed to mentally wife if their household does not get peace anymore. It is permissible for the profit sharing system between farmers who do not have a field rice field with the owner of a field rice field is another form of what is called al-age al-hijayat.

In the field of 'uqubat (criminal), Islam stipulates the obligation to pay fines (diyat) not qisas for people who commit murder unintentionally, offer the right of forgiveness for parents of victims of murder of people who kill their children, and so forth.

c. Tahsîniyyat needs

Tahsîniyyat needs are actions or traits that in principle relate to the noble character, as well as maintenance of the main actions in the field of worship, custom, and mu'amalat. That is, if this aspect does not materialize, then human life will not be threatened by chaos, as if the dharûriyyat aspect did not materialize and it would not bring hardship such as not fulfilling the hajjiyat aspect. However, the absence of this aspect will lead to a condition that is less harmonious in terms of common sense and customs, violating propriety, and reducing personal and community dignity.

The tahsîniyyat aspect in the field of worship, for example, the obligation to think well, practice deeds of charity and charity. Manners apply in eating and drinking or in everyday life, avoiding excessive things, avoiding dirty eating food, and so on are some examples of the tahsîniyyat aspect in the perspective of Islamic law in the field of customs or positive habits.

Furthermore, the prohibition of buying and selling by tricking and hoarding goods to increase the price of the trade, speculation, and so on is an example of the tahsîniyyat aspect in the field of mu'amalat.

The tahsîniyyat aspect in the field of mu'amalat is very much. Therefore, it is necessary to emphasize that the three types of human needs (dharûriyyat, hâjiyat, and tahsîniyyat) above in achieving the perfection of benefit desired by the Shari'ah are difficult to separate from one another. Even though the dharûriyyat aspects are the essential needs, but for their perfection, we need aspects of hajjiyat and tahsîniyyat. Hajjiyat is a complement to dharûriyyat, and tahsîniyyat is perfect for hajiyat, but the dharûriyyat aspect is the basis of all human benefits.

Even though dharûriyyat is said to be the basis for the existence of hâjiyat and tahsîniyyat, it does not mean that the latter two needs are not fulfilled will lead to the loss of dharûriyyat existence. Alternatively, the absence of these two aspects does not interfere with the existence of Dharriyyat as a whole, but for the perfection of the achievement of the Shari'ah goal in prescribing Islamic law, these three types of needs must be fulfilled. This is what is meant that these three needs are one unit that is difficult to separate.

Based on the above description it is clear that knowledge of maqâsid al-shari'ah is very important. Understanding of maqâsid al-syari'ah can be used as a tool in understanding the Qur'an and as-sunnah, it can also help resolve conflicting arguments (ta'arud al-dilalah) and what is very important is maqâsid al- Shari'ah can be used as a guideline for law. By knowing the maqâsid al-syari'ah this will facilitate legal experts in practicing the law. If legal science cannot solve a legal event, then by paying attention to the maqâsid al-shari'ah, every legal event will be easily resolved. Therefore it is very appropriate that maqsid al-syari'ah be used as a guideline in law. 


\section{Conclusion}

Allah SWT establishes Islamic law to maintain human benefit, as well as to avoid the madharat both in the world and in the hereafter. In realizing the benefits in the world and the hereafter, according to the ulamas' usul fiqh, there are five basic elements that must be maintained and realized. The five points are religion, soul, mind, descent, and wealth. Humans will get the benefit; if they can maintain the five main aspects; on the contrary, they will obtain kemafsadatan if they cannot maintain the five elements properly. The five points above then by the ulama 'ushul fiqih are said to be al-kulliyyay al-khams which then becomes part of the maqâsid al-syari'ah which later by the ulama' ushul fiqih is used as a guideline in the law and / or tools in determining the law which the case not explicitly stated in both the Qur'an and alHadith.

\section{$5 \quad$ Recomendation}

To realize policies, decisions, and products that are maslahah laws in the world and the hereafter, then decision-makers, legislators and law makers must understand and know maqasid al-shari'ah, because maqasid al-shari 'ah can be used as a guide in establishing law.

\section{References}

[1] Abadi, Fayruz, Al-Qamus al-Muhit, Beirut: Muassasah al-Risalah, 1987

[2] Al-Muqrī, Ahmad bin Muhammad bin Ali al-Fayumī, Al-Misbah al-Munīr fî Garib al-Sharh alKabir li al-Rafi' 'i, Libanon: Maktabah Lubnan, 1987

[3] Al-Salām, Izz al-Dīn Abd, Qawā'id al-Ahkām Fī Masālih al-Anām, Vol. 1, Kairo: al-Istiqamat, t.t.,

[4] Ashshofa, Burhan, Legal Research Method, Jakarta: Rineka Cipta, 2012

[5] Azizah, Imroatul, "Riddah Sanction Maqâsid al-Sharî'ah Perspective", Al-Daulah: Islamic Law and Law Journal Volume 5, Nomor 2, Oktober 2015; ISSN 2089-0109.

[6] Bogdan, Robert, and Steven J. Taylor, Introduction to Qualitative Research Methods, New York, 1975.

[7] Creswell, John W., Qualitatif Inquiry and Research Design: Chosing Among Five Traditions, London: Sage Publications, 1998.

[8] Djazuli, H.A., Fiqh Science Extracting, Developing and Implementing Islamic Law, Jakarta: Prenada Media, 2015.

[9] Fanani, Ahwan, Horizon Ushul Fikih Islam, Semarang: Karya Abadi Jaya, 2015.

[10] Harahap, Zul Anwar Ajim, "The Maqsid al-Sharia Concept as the Basis for its Establishment and Application in Islamic Law According to Izzuddin ibn Abd al-Salam (W.660 H)", Tazkir Journal Vol. 9 No. July-December 201.

[11] Kaelan, Religious Research Method: Qualitative Interdisciplinary, Yogyakarta: Paradigma, 2012.

[12] Kamali, Muhammad Hashin, Principles of Islamic Yurisprudence, Kuala Lumpur: llmiah Publisher Sdn, BHD, 1998

[13] Khalâf, Abd al-Wahhâb, 'Ilm Usûl al-Fiqh, Kuwait: Dâr al-Qalam, 1978.

[14] Ma'arif, Samsul, et al. Progressive Fiqh Responds to the Challenges of Modernity, Jakarta: FKKU Press, 2013

[15] Manan's, Abdul, Dissertation, Islamic Law Reform in Indonesia, Jakarta: Raja Grafindo Persada, 2016.

[16] Mandzur, Abu al-Fadl Muhammad bin Mukrim bin, Lisan al-Arab, vol.3, Dâr Shâdir, 1300 H

[17] Praja, Juhaya S., Islamic Law Philosophy, Bandung: LPPM Universitas Islam Bandung, 1995.

[18] Praja, Juhaya S. Legal Theory and Its Application, Bandung: Pustaka Setia, 2011.

[19] Rofiq, Ahmad, Islamic Law in Indonesia, Jakarta: Raja Grafindo Persada, 1997. 
[20] Shiddieqy, TM. Hasbi Ash, Islamic Law Philosophy, Jakarta: Bulan Bintang, 2015.

[21] Soekanto, Soerjono, Introduction to Legal Research, Jakarta: UI Press, 1986

[22] Surjaman, Tjun (editor), Islamic Law in Indonesia: Thought and Practice, Bandung: Remaja Rosdakarya, 1991.

[23] Syah, Ismail Muhammad, Filsafat Hukum Islam, Jakarta: Bumi Aksara, 2016.

[24] Syaltut, Mahmud, Islam, Aqidah wa Syari'ah, Mesriyyah: Dar al-Qalam al-Qahirah, 1966.

[25] Syarifudin, Amir, Ushul Fiqh, Jakarta: Logos Wacana, 2014.

[26] Syathibi, Imam, al-Muwāfaqāt fì Usūl al-Shariah, Beirut: Dār al-Ma'rifah, t.th.

[27] Thohari, Chamim, "Renewal of the Maqāsid Al-Sharī'ah Concept in the Thought of Muhammad Tahir ibn 'Ashur,"Journal Al-Maslahah, Volume 13 Nomor 1 April 2017

[28] Yahya, Mukhtar, dan Fatchurrahman, Basics of Islamic Figh Law Development, Bandung: AlMa'arif, 2010.

[29] Zahrah, Muhammad Abu, Usûl al-Fiqh, Cairo: Dâr al-Fikr al-'Arabi, 1958. 